\title{
胎児期水頭症の治療指針をめぐる問題点
}

\author{
山崎 麻 美 坂 本 博 昭*
}

\section{Problems on Treatment of Fetal Hydrocephalus}

by

Mami Yamasaki, M.D., and Hiroaki Sakamoto, M.D.*

from

Department of Neurosurgery, National Hospital Organization Osaka National Hospital, and

${ }^{*}$ Department of Pediatric Neurosurgery, Osaka City General Hospital

We discussed the treatment guidelines for fetal hydrocephalus, which has many unresolved clinical and ethical problems. Before delivery, we should make an accurate diagnosis of the basic disease, decide on the time and method of delivery and give information, counseling and support to the parents. As there is no evidence that early treatment of fetal hydrocephalus brings a good outcome, it is usually recommended to have delivery after 37 weeks of gestation and the way of delivery is to be decided by obstetrical indication. The first choice treatment is a ventricular-peritoneal shunt ( $\mathrm{V}-\mathrm{P}$ shunt). $\mathrm{V}-\mathrm{P}$ shunts should be performed on patients whose body weight (BW) is over 2,000-2,500 g. For those under 2,000 g BW, placement of reservoir and intermittent drainage are usually carried out until BW exceeds $2,000-2,500 \mathrm{~g}$. For patients with myelomeningocele, V-P shunts are usually performed several days after the repair. In cases where meningitis is accompanied or the repair is delayed, transit ventricular drainage is recommended before carrying out the $\mathrm{V}-\mathrm{P}$ shunt.

The conditions in foreign countries and the present situation of intrauterine surgery are also discussed.

(Received September 6, 2005; accepted September 22, 2005)

Key words : fetal hydrocephalus, treatment, guideline

Jpn J Neurosurg（Tokyo） $15: 114-120,2006$

\section{はじめに}

胎児期水頭症は胎内診断される先天性水頭症で, 胎児 超音波検查が一般的になった現在では, 先天性水頭症の 6 割近くを占める。出生前に診断されるために, 診断す る側にも，診断を受ける側にも大きな問題を提起する.

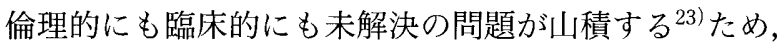
厚生労㗢省難治性疾患克服研究事業先天性水頭症調査研 究班（班会議）では，胎児期水頭症ガイドライン作成委 員会を形成し，胎児期水頭症に関して解決されている問 題と今後に残された問題点を整理し, 胎児期水頭症診断
と治療のガイドライン17)を提案した。ここではその作成 の過程で出てきた問題点を整理し論じる.

\section{胎児期水頭症をめぐる諸外国の現状と わが国の役割}

\section{1 諸外国での現状}

出生前診断を巡っては，各国の宗教的，倫理的，ある いは経済的背景によりその考方方は千差万別であり，さ まざまな方向へ進展している，西欧の主な国(イギリス， フランス, ドイッ, オランダ) やアメリカの幾つかの州

独立行政法人国立病院機構大阪医療センター脳神経外科 $/ \overline{\mathrm{T}} 540-0006$ 大阪市中央区法円坂 2-1-14〔連絡先：山崎麻美〕 Address reprint requests to: Mami Yamasaki, M.D., Department of Neurosurgery, National Hospital Organization Osaka National Hospital, 2-1-14 Hoenzaka, Chuo-ku, Osaka-shi, Osaka 540-0006, Japan

*大阪市立総合医療センター小児脳神経外科 


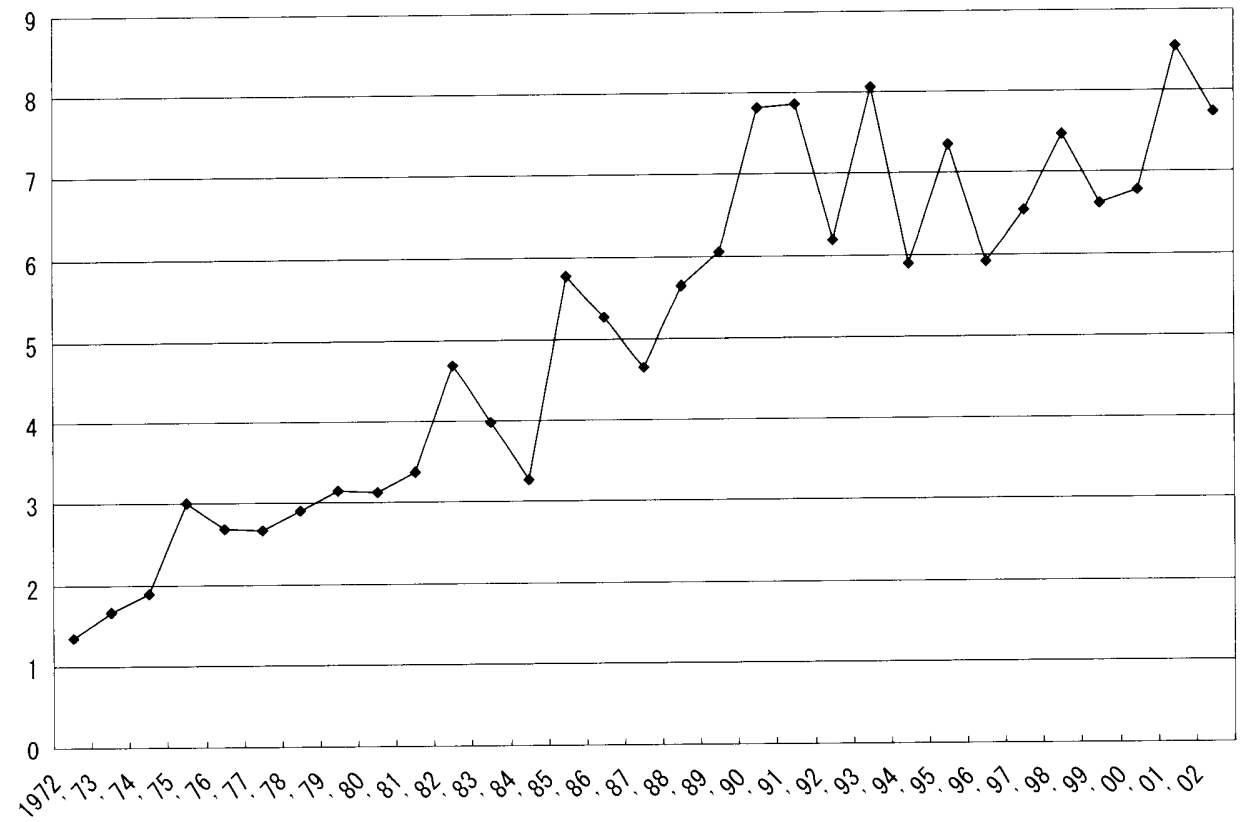

Fig. 1 Incidence of fetal congenital hydrocephalus

According to the database of congenital anomaly monitoring maintained out by the Japanese Gynecologist Association as part of the International Clearinghouse for Birth Defects Monitoring Systems, the occurrence of congenital hydrocephalus is increasing and found in 7 to 8 cases for each 10,000 live births (the data was contributed by Prof. Y Sumiyoshi and Prof. F Hirahara.).

では，妊娠中期から後期まで，時には予定日直前でも， 児が重篤な疾患があるという理由で妊娠中絶（termination of pregnancy；TOP）が行われているところもあ る ${ }^{4) 21)}$. しかし, アイルランド, スペイン, あるいはア メリカの幾つかの州のように宗教的影響の強い地域や中 絶反対派の影響の強い地域では，妊娠中絶には慎重な態 度を取っている。それゆえ, 胎児超音波検査が発展して きた 90 年代前半以降, 胎児期水頭症に関する論文はこ のようなさまざまな異なった背景のうえにあり, 特に治 療予後に関してのデータはそのことを加味して検討寸る 必要がある。

\section{2 わが国の現状}

このような中で，わが国の現状はどういう位置にある のか. 1966 年, 兵庫県が「不幸な子供を生まない」対策 室を設立し, 積極的に羊水検査を行い, 染色体異常児を 早期に診断し生まないことを缶めてきた。これは当然の ことながら障害者団体の強い批判にあい, 74 年には取り 下げたが，この頃から出生前診断は常に病気の胎児を排 除するためと捉えられ, 患者さんの団体からは問題にさ れてきた。わが国の母体保護法では，胎児が病気である という理由では人工妊娠中絶は認められていない。しか し一方では, 経済的理由などの理由での人工妊娠中絶は,
妊娠 22 週未満では認められており, その数は年間 30 万 件を超えている。

このような状況の中で, 現実には産科の外来では胎児 エコー検査が日常的に行われており, 先天性水頭症の中 に占める胎児期水頭症の割合は, 厚生労㗢省先天性水頭 症調査研究班が実施した全国疫学調査（以下，全国疫学 調査)の結果によると, 1987 年 ${ }^{24)}$ に比べ, 1999 年の調査 ${ }^{11)}$ では $22 \%$ から $55 \%$ と約 3 倍に増加し, 約 $60 \%$ に達して いる。胎児期水頭症の診断時期を先の疫学調査の結果で みてみると, 22 週未満の診断は $4 \%$ と少ないし, わが国 で胎児が水頭症であるという理由で妊娠中絶されている 正確な数は把握できないが，諸外国に比べきわめて少な いと考えられる。それゆえ, 班会議が 3 回にわたって実 施してきた全国疫学調査（1987 年，1993 年，1999 年） のデー夕は, 諸外国には類をみない貴重なものである ${ }^{10)}$. 1999 年の第 3 次全国疫学調査だけでも, 1 次調査は全国 1,861 施設から回答があり,こと細かく記載された 2 次 調查票は 150 名の医師から 423 症例の回答に上る.

\section{胎児期水頭症の現状}

\section{(1) 疫 学}

WHO の主導による世界規模の情報交換システムー 
Table 1 Fetal hydrocephalus $(n=219)$

\begin{tabular}{|c|c|c|c|c|}
\hline \multirow{12}{*}{ Primary hydrocephalus } & \multirow{6}{*}{$\begin{array}{l}\text { Hydrocephalus showing } \\
\text { ventriclomegaly as a main finding }\end{array}$} & \multirow{3}{*}{ Simple hydrocephalus } & Simple ventriclomegaly & \multirow{6}{*}{$14 \%$} \\
\hline & & & Aqueduct stenosis & \\
\hline & & & Autosomal recessive & \\
\hline & & \multirow{3}{*}{ Syndromic hydrocephalus } & $\mathrm{X}$ linked hydrocephalus & \\
\hline & & & Walker-Warburg syndrome & \\
\hline & & & HARD $\pm \mathrm{E}$ syndrome & \\
\hline & $\begin{array}{l}\text { Hydrocephalus associated with } \\
\text { myelomeningocele }\end{array}$ & & & $36 \%$ \\
\hline & Dandy-Walker syndrome & & & $6 \%$ \\
\hline & Holoprosencephaly & & & $4 \%$ \\
\hline & $\begin{array}{l}\text { Hydrocephalus associated with } \\
\text { cranial bifida (encephalocele) }\end{array}$ & & & $6 \%$ \\
\hline & $\begin{array}{l}\text { Hydrocephalus associated with } \\
\text { arachnoid cyst }\end{array}$ & & & $2 \%$ \\
\hline & $\begin{array}{l}\text { Hydrocephalus associated with } \\
\text { agenesis of corpus callosum }\end{array}$ & & & $11 \%$ \\
\hline \multirow{7}{*}{ Secondary hydrocephalus } & Post hemorrhagic hydrocephalus & & & \\
\hline & $\begin{array}{l}\text { Hydrocephalus associated with } \\
\text { fetal braintumor }\end{array}$ & & & \\
\hline & \multirow{2}{*}{ Post meningeal hydrocephalus } & Toxoplasmosis & & $7 \%$ \\
\hline & & Cytomegalovirus infection & & \\
\hline & \multirow{2}{*}{$\begin{array}{l}\text { Hydrocephalus associated with } \\
\text { vascular disease }\end{array}$} & Galen AVM & & \\
\hline & & Dural AVM & & \\
\hline & Hydro anencephaly & & & $3 \%$ \\
\hline Others & & & & $11 \%$ \\
\hline
\end{tabular}

\section{Outcome}
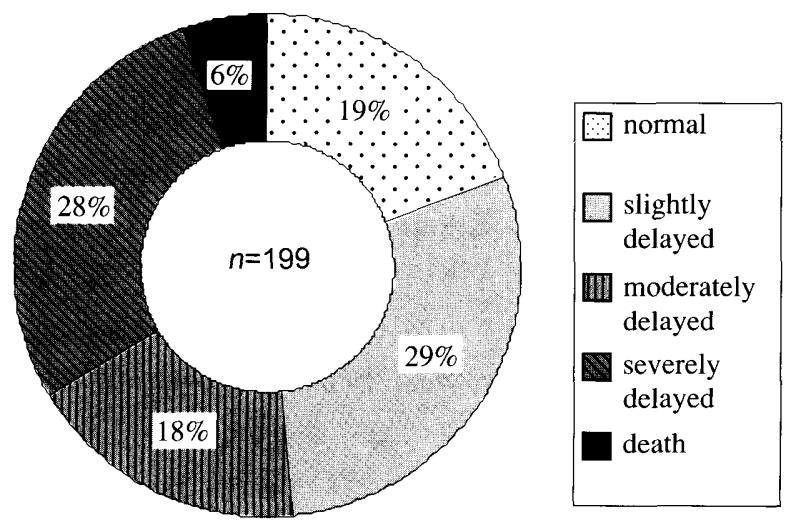

Fig. 2 Outcome of fetal hydrocephalus

The data was obtained from nation-wide surveillance performed by the Research Committee of Intractable Hydrocephalus in 1999 and funded by the Ministry of Health, Labor and Welfare of Japan.
ICBDMS (International Clearinghouse for Birth Defects Monitoring Systems; 国際先天異常監視機構)の日本支部 （代表：住吉好雄教授, モニタリングセンター長：平原史 樹教授）で集約している日本産婦人科医会先天異常モ二 タリングのデータベースは, 出生時に診断されている先 天異常児を全国約 200 のモニター施設からの届け出を 基に集約しており，わが国の総分娩数の $10 \%$ 網羅する ものである ${ }^{16)}$. この住吉教授，平原教授のご好意により 提供いただいたデータベースより作成した先天性水頭症 の発生数の推移を表すグラフを示す（Fig. 1). このデー 夕は, 胎児期水頭症の推定発症率が 10,000 出生当たり 2.1 人という 1992 年の全国疫学調查の結果 (この調査で は, 胎内診断例のみであるので少し少ない) と比べても ほぼ同等であり，信頼度の高いものである ${ }^{18)} .1974$ 年頃 の先天性水頭症は 10,000 出生当たり 1 ～ 2 人であったの に対し，10,000 人出生当たり 8.5 (2001 年), 7.7 (2002 年）と約 7 8 倍に増えている. また先天異常児全体の 平均 $4.7 \%$ （2000～2002 年）を占め，発症数において心 室中隔欠損症，ダウン症，口唇・口蓋裂などに次いで 4 


\section{Hydrocephalus}

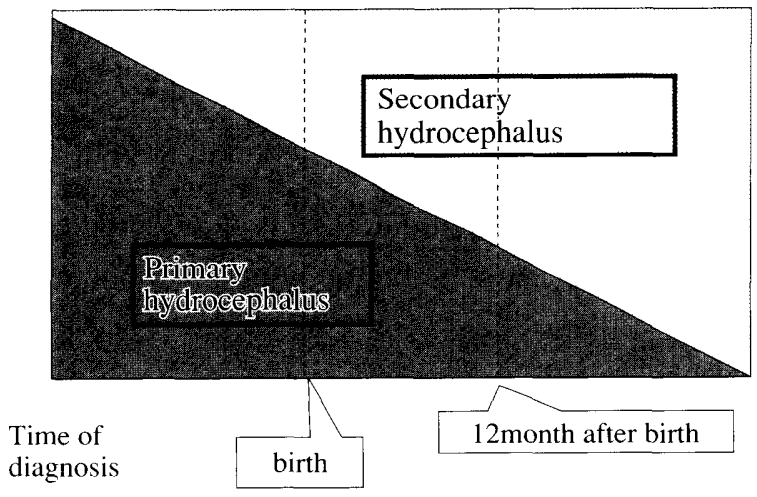

Congenital hydrocephalus

Fetal hydrocephalus

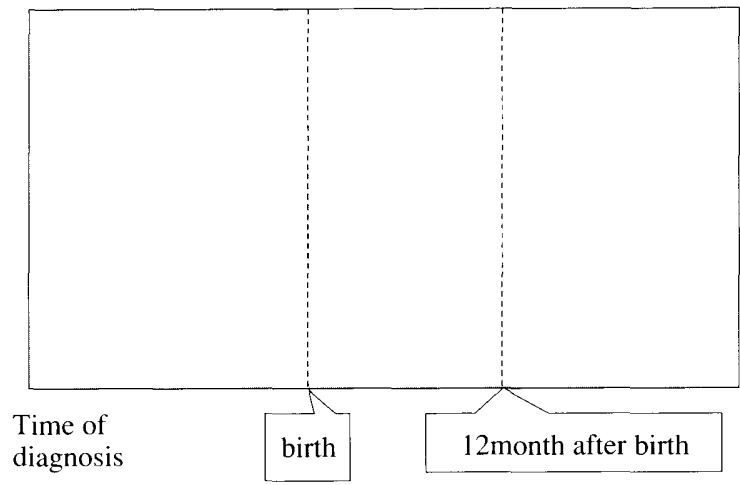

Congenital hydrocephalus

Fetal hydrocephalus

Fig. 3 The definition of congenital hydrocephalus and fetal hydrocephalus

Fetal hydrocephalus consists of both primary hydrocephalus and secondary hydrocephalus diagnosed antenatally. Congenital hydrocephalus consists of both fetal hydrocephalus and primary hydrocephalus diagnosed postnatally.

番目に多い疾患である ${ }^{17)}$ 。これは発症率が高くなつてい るというよりも，胎児超音波検査の進歩により胎児期の 診断率が高くなつたことの表れであると推察される.

\section{2 分 類}

胎児期水頭症は単一の疾患ではなく, 種々の疾患が集 まったものである.言葉の定義は次項で述べる. 1999 年 の全国疫学調查の結果 ${ }^{11)} よ り$ 作成したその内訳と頻度 を Table 1 に示す.

\section{[3] 転 帰}

基礎疾患や併発する病態により転帰はさまざまであ る. 後遺症なく健康 $19 \%$, 介助なしで日常生活が可能な

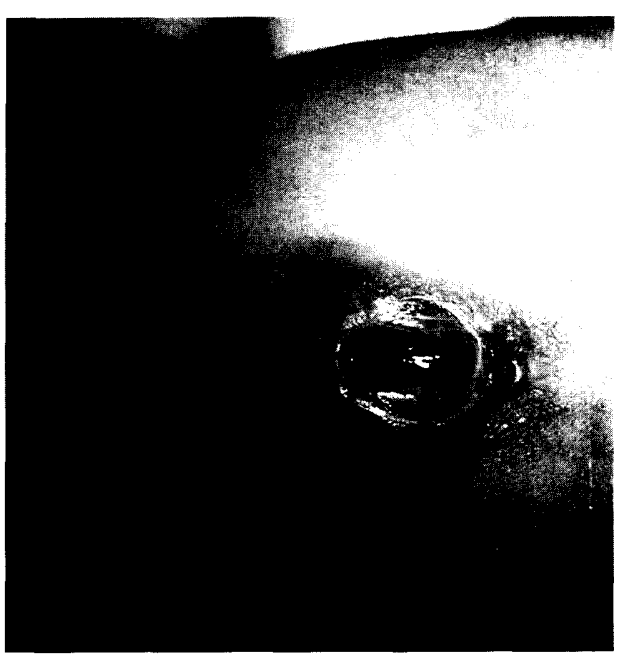

Fig. 4 Myelomeningocele

The neural placode, the part of the neural plate that failed to fuse, is not covered by the normal skin and is exposed to the surface with a groove in its center.

ものは $29 \%$ という半面, 中等度の発達遅滞を後遺してい るものは $18 \%$, 全面介助や死亡例はそれぞれ $28 \% ， 6 \%$ だった ${ }^{11)}$ (Fig. 2).

\section{胎児期水頭症の言葉の定義}

胎児期水頭症の診療にかかわるのは脳神経外科だけで はなく, 産科, 小児科, 臨床遺伝と多くの科が関与して いる。 ガイドライン作成作業の中で議論に不可欠な要素 として, まず言葉の定義 (共通言語) の確認が必要であつ た。

\section{1 先天性水頭症と胎児期水頭症}

発生過程の異常によるものを原発性水頭症と呼ぶのに 対し, 続発性水頭症は, 出血や感染など何らかの障害が 加わったり, 腫瘍や血管障害が随伴することにより水頭 症を発症したものを呼ぶ. 胎児期水頭症は, 胎内で診断 された原発性水頭症と続発性水頭症を指す。先天性水頭 症は，胎児期水頭症と生後診断された原発性水頭症を呼 ぶ. (Fig. 3). 先天性水頭症の多くは 1 歳頃までに暗断さ れるが，それ以降の小児期や，稀には成人期に初めて診 断されることもある。

\section{2) 脊髄髄膜瘤について}

腰仙部に神経組織が露出し，多くの場合水頭症を伴う 病態に関して，顕在性二分脊椎症，囊胞性二分脊椎，キ アリ奇形，脊髄䯣膜瘤，脊髄被裂などとさまざまに呼ば れているが，以下のような理由で，ガイドラインでは単 
純に脊髄髄膜瘤（myelomeningocele）と呼んだ.

二分脊椎は慣用的によく用いられている言葉である が，これは春髄髄膜瘤と同義で使われる顕在性（唾胞性） 二分准椎と春髄脂肪腫に代表される潜在性二分脊椎を含 む. 顕在性二分脊椎症では, 神経管が癒合しないため形 成異常をきたした神経組織（placode）が皮膚に覆われず に外表に露出している病態を現しており，潜在性二分脊 椎とは病態がまったく異なる。また脊髄披裂は, placode の下に瘤が形成されていないだけで，病態は基本的に同 じである（Fig.4）.

またキアリ奇形が同義語として使われることがある が, 脊髄髄膜瘤と関係の深いのはキアリ II 型奇形であり, キアリ I 型奇形は別の病態である。ただしキアリ II 型奇 形は脊髄髄膜瘤全例に伴うものではないので，これを脊 髄髄膜瘤と同義に用いるのは不正確である。

\section{治療指針をめぐる問題点}

\section{1] 胎内治療の歴史}

1980 年代に胎児期水頭症に対する胎内治療の試みが 施行されたのは，早期治療による予後の改善を期待した ものである。しかしながら，それが悲惨な結果に終わつ て以降は，早期治療が予後の改善をもたらすという考え は，肺の成熟が許す限り早期に娩出して早期に治療する という方針に引き継がれていた。しかし，37 週の正期産 以前の早期に姢出して早期治療することが予後を改善し たという報告はない14).

しかし再び, 1997 年からアメリカの一部の施設では春 髄髄膜瘤に対する胎内治療が開始された。替髄髄膜瘤の 胎内治療を推し進めている Tulipan らは, 最近の報告 ${ }^{19)}$ でも，胎内治療は脊髄機能の改善に効果は少ないがキア リ奇形の発症率とシャント手術が必要な水頭症の発症率 の低減には効果的であると報告している，アメリカの 3 つの施設で行った 104 例の胎内治療例を従来の出産後 治療群 189 例と比較し, シャント手術が必要な水頭症の 割合が，胎内治療では $85.7 \%$ から $54.8 \%$ に減少し，特に sacral level では $67.5 \%$ から $26.7 \%$ と顕著に低下してお り，かつ 25 週以前で胎内治療が行われた群では，シャ ント必要例が全体で 44.1\%, sacral level で 25\%であった というものである。しかしながら，一方，Vanderbilt大 学とフィラデルフィア小児病院での胎内治療が原因の死 亡率は $4 \%$ ，重篤な後遺症は $11 \%$ であった ${ }^{20)}$ 。合併症は 児のみならず母親にも及び，春髄髄膜瘤は致死的な疾患 ではないし，ましてや次子の出産への影響を生ずるので あれば，この合併症は無視できない.これを克服するた
めに，内視鏡を利用してテクニックを改善するという方 向へ進んでおり, 2003 年より 200 例を対象に胎内治療と 従来の出生後治療の randomized trial (MOMS; Management of Myelomenigocele Study）を開始し，2003 年末ま でに 30 例が study に参加し，単純計算で follow-up 2 年半以上として, 結果が得られるのは 2011 年になるだ ろうと予想している20).

しかし, 脊髄髄膜瘤に合併する水頭症は, 適切な治療 を行えば他の水頭症に較べて知的発達がよく，確かにキ アリ II 型奇形が症候性で治療に難啮する場合，死亡率も 高いが，キアリ II 型奇形が症候性であるのはせいぜい $10 \%$ で，その中には早期に大孔減圧術を施行すれば症状 を解決できる例もあることも事実である. 從来の治療法 が到達している水準を胎内治療が上回るかどうか，その 結果を厳しくみていく必要がある。また一方ではイギリ スの Bannister ${ }^{1)}$ は，春髄髄膜瘤の TOP が現在では $80 \%$ 近い, と報告し, 胎内治療は, 両親から TOP の機会を奪 うものだという批判をしているが，こういう観点からの 批判はわれわれの感覚では受け入れがたいものである。

\section{2 出生までにやらなければいけないこと}

現在までのところ，このように安全で有効な胎内治療 が存在しないので，わが国では胎児期水頭症はすべて出 生後治療である。出生前に診断されて生まれるまでの時 期にやらないといけないことが幾つかある，基礎疾患の 診断，出産時期と方法の決定，そして母親や父親に対す る説明とカウンセリングである，説明は，考えられる疾 患名を単に挙げるのみではなく, その病態, 治療方法, 予後などに関して，その時点でわかりえる情報について， 参考になる図を提示したり，専門用語を噛み砕いて解説 し，かつ説明に用いる言葉の使い方などにも配慮し慎重 に行う。両親は予期していなかった事態やこれから起こ ることに不安を抱いている，母親が病気を持った子供を 生んだという責任を強く感じている場合もある。母親や 父親の負担を和らげるように，かつ児に不利益とならな いことを念頭に置きながら, 出生した後に愛情を持って 児を受け入れられるように，社会的支援などの情報も提 供しながら, 説明やカウンセリングは繰り返し行う12)15).

\section{3 胎児期水頭症に関する出生時期と出生方法の 決定}

一時期，早期治療が予後を改善するという主張があつ たが，現在では異論も多い。胎児期水頭症の中で脳室の 進行性拡大を示すのは 2.5 4.5\% と少なく ${ }^{15)}$, 脳室の進 行性拡大がなければ，原則的に妊娠 37 週 0 日以後の正 
期産とする。また進行性拡大が認められる場合でも，正 期産の 37 週より早く出生させれば予後が改善するとい う報告はほとんどない，逆に，肺の成熟が完了する前に 出生させた場合, 生命予後を左右する頭蓋内出血や呼吸 器合併症などを併発し，新生児科（小児科）による慎重 な全身管理が必要となることはもちろん，厳密な管理を してもかえって予後が不良になることもある.出生時期, 分婏方法は，ほとんどの場合，産科的適応による．水頭 症のため児頭が大きく児頭骨盤不均衡があれば，陣痛発 来までに帝王切開を行う。春髄髄膜瘤の場合, 陣痛や産 道を通過することが露出した neural plaque に対するダ メージを与えると考え, 陣痛発来前に帝王切開で分婏す ることが推奨されてきだ ${ }^{4)}$ が，帝王切開が経胵分娩と比 ベて機能的に悪くしてしまうようなことはないという論 文5)6) みら机, 帝切の適応があるのかかどうか他施設共 同の trial の必要を説いている論文 ${ }^{8)} あ り り$ まだ議論の 残るところである.

\section{4. 出生後の外科的治療方針}

水頭症に関しては脳室-腹腔シャント術（V-P シャン 卜術）が第一選択である。生後早期の第三脳室開空は, 視床間橋が大きいため第三脳室底が観察し難いことや, 新生児期は髄液吸収障害を伴っているため有効ではない とされ(2)19)，モンロー孔閉塞症や囊胞性病変など特殊な 場合を除き対象にならない，また使用するバルブは，成 長に従ってシャントの至適圧が変わるので压可変式バル ブが有効であるという報告もあり，圧可変バルブを使用

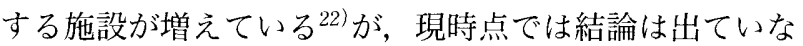
い. 脳室心房シャントは, シャント感染で敗血症をきた すため第一選択にはしない. 水頭症児が低体重の場合, 体重が $1,500 \mathrm{~g}$ 以上で V-P シャント術が可能13) という報 告もあるが，合併症の危険を可能な限り低くする観点か らは, シャント手術時の体重は $2,000 \sim 2,500 \mathrm{~g}$ 以上が望 ましい. 出生時体重 $2,000 \mathrm{~g}$ 以下では出生後全身状態が 安定し次第, リザーバー設置術を施行し, 以後, リザー バーから必要に応じて髄液穿刺排液を行いながら，体重 2,000 2,500g を超え, 全身状態が落ち着いてから, 手 術施行するのが一般的である ${ }^{15)}$. ただし著明な水頭症の 場合，実際の体重よりも頭部の重さを考慮して，少し少 なめに見積もる必要がある。

\section{5] 脊髄髄膜瘤の水頭症の手術のタイミング}

最も頻度の多い春髄髄膜瘤に伴う水頭症の治療方針に ついて述べる．生下時に治療を行う必要のある高度の水 頭症は約 $15 \%$ にみら, 残りの例は瘤を修復して生後 6
週間までに水頭症が顕在化し治療が必要となるといわれ ている. 生後 5 力月を過ぎて治療の必要な水頭症の顕在 化は稀である。青髄髄膜瘤の水頭症におけるシャント合 併症は 29〜 66\% と他に比心゙非常に高いものである.修復 の後にシャント術を行った場合，シャント感染は $7.3 \%$ に発症し，同時の施行では $23 \%$, シャント術の後に修復 した例の感染率は $83 \%$ というデータや, 生後 2 日以降に 修復し，かつ修復と同時にシャントすれば $75 \%$ で感染を 起こすというデータがある3)。一方では脊髄髄膜瘤の修 復と同時にシャントを行っても合併症のリスクは変わら ないという報告7)9)もあり，施設によって方法は異なる が，修復後しばらくしてシャント術を行うほうが一般的 である ${ }^{3)}$ 。ちろん䯣膜炎を併発していたり, 修復が遅 れた場合は，いったん脳室ドレナージを置くことが望ま しい.

\section{おわりに}

ここに述べたことは胎児期水頭症の治療指針の一部で あり，診断に関しての問題点は今回省略した。またこれ らのより詳細な内容は, 厚生労働省難治性疾患克服研究 事業「先天性水頭症」調査研究班（平成 11 16 年) の 研究成果により作成された『胎児期水頭症一診断と治療 ガイドライン』（胎児期水頭症ガイドライン編集委員会 編) ${ }^{17)}$ に記載されている。

\section{文 献}

1) Bannister $\mathrm{CM}$ : The case for and against intrauterine surgery for myelomeningoceles. Eur J Obstet Gynecol Reprod Biol 92: 109-113, 2000.

2) Buxton N, Macarthur D, Mallucci C, Punt J, Vloeberghs $\mathrm{M}$ : Neuroendoscopic third ventriculostomy in patients less than 1 year old. Pediatr Neurosurg 29: 73-76, 1998.

3) Caldarelli M, Di Rocco C, LaMarca F : Shunt complication in the first postoperative year in children with meningomyelocele. Childs Nerv Syst 12: 748-754, 1996.

4) Cochrane D, Aronyk K, Sawatzky B, Wilson D, Steinbok $P$ : The effect of labor and delivery on spinal cord function and ambulation in patients with meningomyelocele. Childs Nerv Syst 7: 312-315, 1991.

5) Lewis D, Tolosa JE, Kaufmann M, Goodman M, Farrell C, Berghella V: Elective cesarean delivery and long-term motor function or ambulation status in infants with meningomyelocele. Obstet Gynecol 103:469-473, 2004.

6) Luthy DA, Wardinsky T, Shurtleff DB, Hollenbach KA, Hickok DE, Nyberg DA, Benedetti TJ: Cesarean section before the onset of labor and subsequent motor function in infants with meningomyelocele diagnosed antenatally. $N$ Engl J Med 324: 662-666, 1991.

7) Machado HR, Santos de Oliveira R: Simultaneous repair of myelomeningocele and shunt insersion. Child's Nerv Syst 
20: 107-109, 2003.

8) Merrill DC, Goodwin P, Burson JM, Sato Y, Williamson R, Weiner CP: The optimal route of delivery for fetal meningomyelocele. Am J Obstet Gynecol 179:235-240, 1998.

9) Miller PD, PollackIF, Pang D, Albright AL : Comparison of simultaneous versus delayed ventriculoperitoneal shunt insersion in children undergoing myelomeningocele repair. J Child Neurol 11: 370-372, 1996.

10）森竹浩三，上村岳上，宮崎健史，玉腰暁子，川村 孝, 稲葉 裕, 秦 利之, 大井静雄, 山崎麻美: 胎児水頭症 疫学調査研究 15 年の軌跡. 厚生科学研究特定疾患対策研 究事業, 難治性水頭症調査研究班, 平成 14 年度研究報 告書. 2003, pp.90-94.

11）中山登志子, 玉腰暁子, 川村 孝, 稲葉 裕, 森竹浩三, 山崎麻美: 先天性水頭症全国疫学調査成績. 厚生科学研 究特定疾患対策研究事業, 難治性水頭症調査研究班, 平 成 12 年度研究報告書. 2001, pp.83-94.

12）夫 律子：フルカラーアトラス。最新 $3 \mathrm{D} / 4 \mathrm{D}$ 胎児超音 波画像診断。大阪，メデイカ出版，2004.

13) Rekate $\mathrm{H}$ : Treatment of hydrocephalus. in Albrigth AL, Pollack IF, Adelson PD (eds): Principle and Practice of Pediatric Neurosurgery. New York, Thieme, 1999.

14) Rosseau GL, McCullough DC, Joseph AL: Current prognosis in fetal ventriculomegaly. $J$ Neurosurg 77:551-555, 1992.

15）坂本博昭，北野昌平：先天性水頭症の診療における脳神
経外科医の役割。脳外誌 13：465-472，2004.

16）住吉好雄：先天異常モニタリング等に関する研究. 平成 11 年度厚生科学研究 (子ども家庭総合研究事業).

17）胎児期水頭症ガイドライン編集委員会編：胎児期水頭症 一診断と治療ガイドライン第 1 版。京都, 金芳堂, 2005.

18）玉腰暁子, 大野良之, 川村 孝, 森 惟明, 森竹浩三, 前田博敬, 渡辺一功, 根来良子, 大井静雄: 胎览期水頭 症の受療患者数の推計。厚生省特定疾患難治性水頭症調 査研究班，平成 6 年度研究報告書，1995, pp.11-13.

19) Teo C, Jones R: Management of hydrocephalus by endoscopic third ventriculostomy in patients with myelomeningocele. Pediatr Neurosurg 25: 57-63, 1996.

20) Tulipan $\mathrm{N}:$ Intrauterine closure of myelomeningocele: An update. Neurosurg Focus $15: 1-4,2004$.

21) Twining $\mathrm{P}$, Jaspan $\mathrm{T}$, Zuccollo $\mathrm{J}$ : The outcome of fetal ventriculomegaly. $B r J$ Radiol 67 : 26-31, 1994.

22）上村岳士, 森竹浩三, 中山登志子, 玉腰暁子, 川村 孝, 稲葉 裕, 山崎麻美: 先天性水頭症全国疫学調査一出生 時期と手術時期による臨床像の比較. 厚生科学研究特定 疾患対策研究事業, 難治性水頭症調査研究班, 平成 13 年度研究報告書. 2002, pp.38-43.

23）山崎麻美: 先天性水頭症の診療一未解決の問題点. 脳外 誌 $13: 473-481,2004$.

24）渡辺一功, 玉腰暁子, 佐々木隆一郎: 先天性水頭症全国 疫学調査. 厚生省特定疾患難治性水頭症調査研究班, 昭 和 63 年度研究報告書, 1989 , pp.110-114.

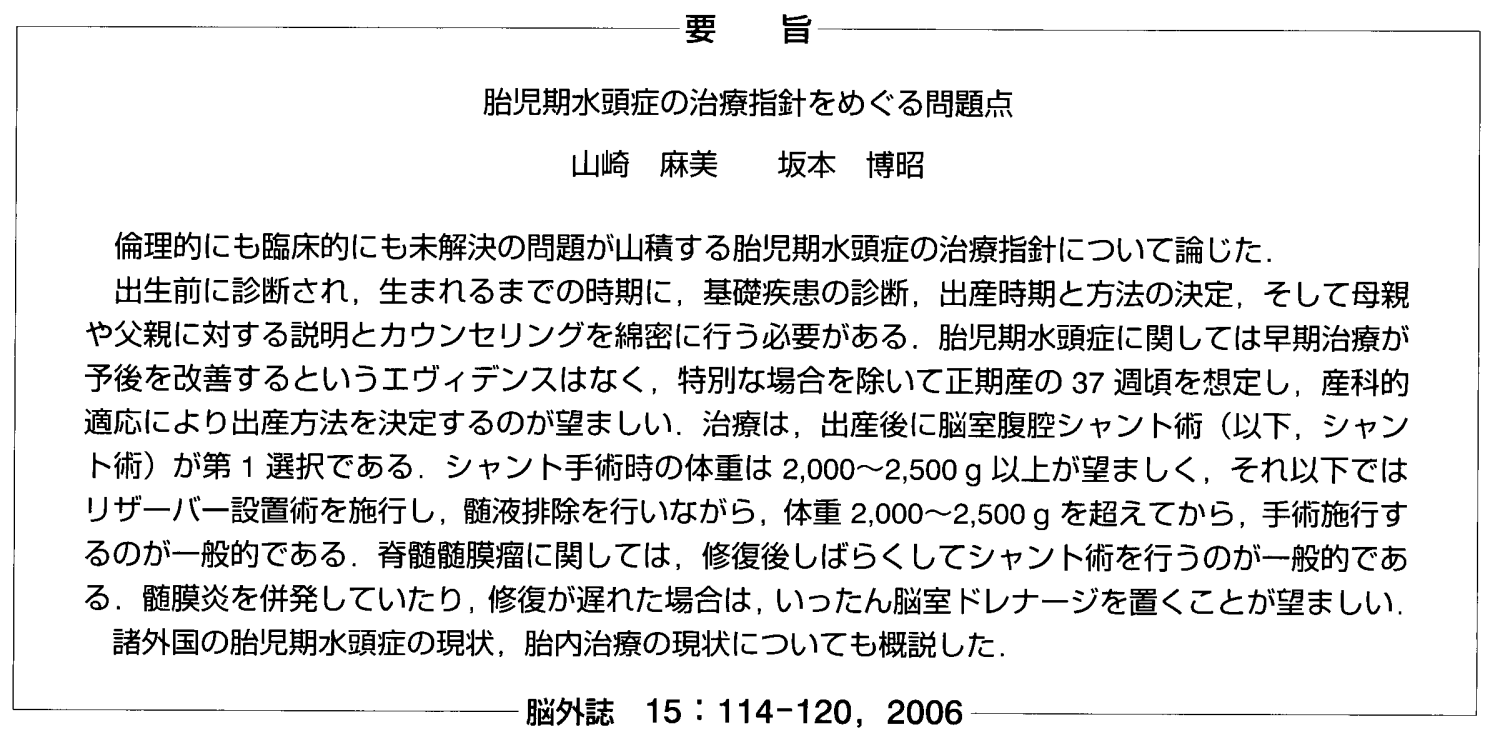

